\title{
INVESTASI SAHAM: INVESTASI, SPEKULASI, ATAU JUDI
}

\author{
Indahwati \\ Fakultas Ekonomi dan Bisnis, Universitas Wijaya Kusuma Surabaya \\ email: indahwati@uwks.ac.id
}

\begin{abstract}
Stocks are proof of company ownership, which is attractive for investment. Often people become doubtful about investing in stocks, which are considered gambling. This study tries to find answers from the perspective of financial science about investment criteria, speculation and gambling. The method used in this study goes through stages starting with understanding stocks and the mechanism of stock trading to the decision of investors in buying or selling shares. The results obtained show that from a theoretical perspective, investment is different from speculation and gambling. Investing in stocks is not gambling, but it can be speculation or investment, depending on the attitudes and expectations of the investors themselves. When investors are risk takers and only expect capital gains without considering financial performance, this is speculation known as liquidity traders. When investors expect dividends by considering the condition of the company and other aspects, this is an investment known as an information trader. The implication of this study is that an investor must be rational in the sense of calculating risk that is proportional to the expected results.
\end{abstract}

Keywords: stocks, investment, speculation, gambling

\section{PENDAHULUAN}

Investasi merupakan kegiatan untuk memperoleh keuntungan, sementara saham merupakan bukti kepemilikan perusahaan yang menarik untuk investasi. Hubungan antara aktivitas pasar keuangan dengan judi sudah menjadi perdebatan, sering orang menjadi ragu tentang investasi dalam saham, yang dianggap sebagai judi. Hal serupa dikemukakan oleh (Kumar, 2009), within the financial sector, it is common to identify certain stock market activities as gambling-like. Banyak orang beranggapan bahwa saham adalah sesuatu yang tidak terlihat dan ada juga yang beranggapan bahwa ketidakpastian saham itulah sebenarnya judi. Apakah memang membeli atau melakukan investasi dalam saham adalah judi, studi ini berusaha untuk melakukan studi dari perspektif teori keuangan dan teori investasi.

Tujuan dari studi ini adalah untuk mencari kebenaran secara teoritis atas berbagai keraguan masyarakat mengenai investasi saham, sehingga dapat digunakan sebagai acuan dalam mengambil keputusan investasinya.

\section{Permasalahan}

Apakah investasi dalam saham merupakan judi, dan kriteria apa yang bisa digunakan sebagai pegangan masyarakat untuk melakukan investasi saham tanpa harus merasa ragu akan tindakan

investasinya saham tanpa harus merasa ragu akan tindakan investasinya.

\section{Tinjauan Literatur}

Harapan investor

Saham merupakan bukti kepemilikan atas sebuah perusahaan dalam hal ini perusahaan yang go public. Perdagangan saham diatur oleh Bursa Efek Indonesia (BEI) yang diawasi oleh Bapepam (Badan Pengawas Pasar Modal) yang menjamin investor melalui Undang-Undang Pasar Modal No. 8 tahun 1995 tentang Pasar Modal. Seorang investor membeli saham atau menginvestasikan dana dalam bentuk saham dengan harapan memperoleh keuntungan atau hasil dari investasinya. Hasil keuntungan yang diharapkan oleh para investor adalah dividend dan capital gain yang dirumuskan sebagai berikut:

$$
K e=\frac{d_{1}}{P_{0}}+g
$$

$$
\begin{array}{lll}
\mathrm{d}_{1} & : & \begin{array}{l}
\text { Dividen tahun depan } \\
\text { yang merupakan harapan }
\end{array} \\
\mathrm{P}_{0} & : \text { Harga saham saat ini } \\
\mathrm{d}_{1} / \mathrm{P}_{0} & : \text { Hasil dividen } \\
\mathrm{g} & : \begin{array}{l}
\text { Pertumbuhan yang } \\
\text { diharapkan }
\end{array}
\end{array}
$$


Dividen merupakan pembagian laba yang diharapkan investor dari hasil operasi perusahaan, sedangkan capital gain merupakan laba ditahan yang akan digunakan untuk investasi kembali untuk pertumbuhan perusahaan. Bentuk konkret dari capital gain adalah keuntungan yang diperoleh investor ketika menjual sahamnya. Harga saham merupakan harga yang terjadi pada saat itu karena mekanisme pasar antara permintaan dan penawaran saham. Penawaran saham berasal dari perusahaan dan investor yang menjual saham dan permintaan saham berasal dari para investor itu sendiri.

\section{Permintaan dan Penawaran Saham}

1. Dari segi permintaan

Permintaan saham berasal dari para investor. Fluktuasi harga sekuritas/saham tampaknya merupakan perputaran yang tidak berarti, tetapi berdasarkan pengujian lebih dekat tampak bahwa harga-harga bergerak di sekitar perubahan nilai yang dialaminya, dan bahwa harga sekuritas dapat dipandang sebagai serangkaian fluktuasi acak yang terkendala sekitar nilai intrinsiknya (Francis, 1993). Kendala merurut model Cootner dapat berasal dari dua kelompok investor yaitu kelompok likuiditas/liquidity trader atau disebut juga spekulator dan kelompok informasi / information trader atau disebut juga professional. Liquidity trader adalah kelompok yang memiliki kelebihan kas yang ingin diinvestasikan atau yang perlu untuk melikuidasi investasinya untuk membayar biaya yang tiba-tiba. Liquidity trader menjual dan membeli pada waktu yang acak dan tidak meneliti sebelum mereka melakukan investasi. Sedangkan information trader mempunyai sumber daya untuk menemukan informasi baru dan mengembangkan estimasi nilai sekuritas. Information trader mengenali berita yang signifikan dari nilai intrinsik dan menganggap perdagangan cenderung mendekatkan harga pasar dengan nilai intrinsik saham.

Menurut (Fama, E., 1955) model Cootner menunjukkan bagaimana harga sekuritas/saham berfluktuasi karena tindakan dari kedua trader tersebut. Liquidity trader yang tidak mendasarkan pada analisis yang tepat tentang berita terakhir, maka ia mungkin akan membeli sekuritas yang harga pasarnya lebih rendah dari nilai intrinsiknya. Setelah itu akan menjual sekuritas bila harga pasarnya lebih tinggi dari nilai intrinsiknya untuk memperoleh keuntungan. Ini akan menyebabkan fluktuasi harga menyebar dari nilainya. Tindakan kedua trader tersebut akan menyebabkan harga bergerak menuju nilai intrinsiknya untuk mencapai ekuilibriumnya.

\section{Dari segi penawaran}

Penawaran saham berasal dari perusahaan penerbit saham dan investor. Perusahaan penerbit saham mengambil keputusan keuangan yang akan membantu mencapai tujuan perusahaan. Tujuan keputusan keuangan adalah memaksimumkan kekayaan pemegang saham atau nilai perusahaan yaitu harga saham perusahaan. Sebenarnya nilai total perusahaan adalah jumlah dari kedua komponen nilai yaitu nilai pasar ekuitas ditambah dengan nilai pasar hutang. Ukuran kekayaan pemegang saham memfokuskan pada kinerja harga saham perusahaan dan mencoba menentukan berapa kenaikan kekayaannya dari satu period ke periode berikutnya berdasarkan dividen yang mereka terima dan apresiasi (capital gain) harga saham perusahaan (Bacidore, J. M. dkk, 1997). Oleh karena itu kekayaan pemegang saham atau nilai perusahaan diwujudkan dalam pemaksimuman harga saham.

Nilai perusahaan yang tercermin dalam harga saham hanya berkaitan dengan aliran laba/cash flow yang dihasilkan, di mana cash flow dapat berasal dari aktivitas operasi, aktivitas pendanaan dan aktivitas investasi seperti dikemukakan oleh (Livnat, J. dan Paul, Z., 1990). Harga saham dihitung dengan mentransformasi rumus (1) menjadi:

$$
P_{0}=\frac{d_{1}}{P_{0}-g}
$$

Harga saham ini menunjukkan harapan investor akan dividen dan capital gain. Bukti menunjukkan (Arthur, Jennifer N., et.al, 2016) bahwa hanya sedikit analis dan pedagang yang sangat mendasarkan pada riset dan informasi untuk memilih investasi mampu secara konsisten mengungguli hasil rata-rata pasar. Investor yang tidak professional umumnya berkinerja buruk dengan bertransaksi tinggi dan memilih produk keuangan dengan risiko lebih tinggi.

\section{Risk and Return}

Investasi berdasarkan jangka waktu bisa dibagi dalam investasi jangka panjang > 5 tahun, investasi jangka menengah 1-5 tahun, dan investasi jangka pendek $<1$ tahun. Sedangkan berdasarkan bentuknya, investasi fisik dan investasi sekuritas. Investasi fisik dapat berbentuk proyek atau pabrik atau penggantian, dan investasi sekuritas dapat berbentuk saham, obligasi, deposito atau 
instrumen-instrumen derivatif, ataupun portofolio. Investasi merupakan suatu cara penanaman modal saat ini dengan harapan untuk memperoleh hasil di masa yang akan datang. Hal ini menunjukkan bahwa terdapat ketidakpastian akan hasil yang akan diterima atau risiko. Risiko didefinisikan sebagai deviasi standar tingkat keuntungan $(\sigma)$, yang menunjukkan seberapa jauh kemungkinan nilai yang diperoleh menyimpang dari nilai yang diharapkan (expected value atau $\mathrm{E}(\mathrm{R})$ ).

Investasi dalam studi ini adalah investasi dalam sekuritas atau saham yang dibagi dalam investasi dalam aktiva bebas risiko (risk-free assets) dan investasi dalam aktiva berisiko (risky assets). Investasi dikatakan bebas risiko apabila hasil yang diharapkan dapat ditentukan dengan pasti, sementara investasi berisiko apabila hasil yang diharapkan tidak dapat ditentukan dengan pasti. Sebagai ilustrasi adalah deposito merupakan investasi bebas risiko, dan saham merupakan investasi berisiko.

Deposito sebagai investasi bebas risiko dapat ditentukan hasil/keuntungan yang diharapkan dengan pasti katakan bunga deposito $6 \%$ per tahun, tanpa risiko. Sementara semua bisnis adalah saham yang berisiko, hasil yang diharapkan belum pasti. Pilihan investasi tergantung pada sikap orang dalam menghadapi risiko, ketika seorang investor adalah risk averter atau orang yang selalu menghindari risiko, maka ia akan memilih deposito. Investor yang bersikap risk taker atau orang yang berani mengambil risiko, akan memilih saham dengan harapan memperoleh hasil yang lebih besar.

Seorang investor haruslah rasional, dalam arti memperimbangkan keduanya yaitu risiko dan hasil yang diharapkan (risk and return). Sebagai ilustrasi katakan dua tempat wisata tidak dapat menentukan dengan pasti keuntungan yang diperoleh, hanya dapat menentukan probabilitas berdasarkan ramai sepinya pengunjung. Ketika kondisi ramai, keuntungan yang diperoleh Tempat Wisata A 15\% dan B sebesar 20\%, kondisi normal Tempat Wisata A memperoleh hasil $10 \%$ dan B sebesar $10 \%$, sedang dalam kondisi sepi Tempat wisata A memperoleh hasil 5\% dan B sebesar $2 \%$. Probabilitas kondisi ramainya pengunjung 30\% pada saat liburan sekolah, probabilitas kondisi normal 30\% yaitu hari Sabtu dan Minggu, sementara probabilitas sepinya pengunjung yaitu $40 \%$ pada hari kerja. Kondisi ini dapat dilihat dalam Tabel 1.
Berdasarkan Tabel 1 dapat dihitung hasil yang diharapkan rata-rata atau expected return masing masing Tempat wisata $\mathrm{E}(\mathrm{R})$ dan risiko $(\sigma)$

$$
\begin{aligned}
\mathrm{E}(\mathrm{RA})= & 0,30(15)+0,30(10)+0,40(5) \\
= & 9,5 \% \\
\mathrm{E}(\mathrm{RB})= & 0,30(20)+0,30(12)+0,40(2) \\
= & 10,4 \% \\
\sigma \mathrm{A} \quad & \sqrt{ }(15-9,5) 2.0,30+(10-9,5) 2.0,30 \\
& +(5-9,5) 2.0,40 \\
= & 4,14 \% \\
= & \sqrt{ }(20-10,4) 2.0,30+(12-10,4) 2 \\
& .0,30+(4-10,4) 2.0,40 \\
= & 6,69 \%
\end{aligned}
$$

Tabel 1

Probabilitas (P) dan Hasil Investasi (R) Masing-masing Tempat Wisata

\begin{tabular}{cccc}
\hline Kondisi & $\mathbf{P}$ & $\mathbf{R}_{\mathbf{A}}$ & $\mathbf{R}_{\mathbf{B}}$ \\
\hline Ramai & 0,30 & $15 \%$ & $20 \%$ \\
\hline Normal & 0,30 & $10 \%$ & $12 \%$ \\
\hline Sepi & 0,30 & $5 \%$ & $2 \%$ \\
\hline
\end{tabular}

Sumber: Data diolah

\begin{tabular}{|c|c|c|c|}
\hline Investasi & $\begin{array}{c}\text { Hasil yang } \\
\text { diharapkan } \\
\text { E }(\mathbf{R})\end{array}$ & Risiko (б) & CV \\
\hline Saham A & $9,5 \%$ & $4,14 \%$ & 0,43 \\
\hline Saham B & $10,4 \%$ & $6,69 \%$ & 0,64 \\
\hline
\end{tabular}

Hasil perhitungan akan ditunjukkan dalam Tabel 2 bahwa Saham A memberikan hasil yang diharapkan sebesar 9,5\% dengan risiko $4,14 \%$, sementara saham B memberikan hasil yang diharapkan lebih besar yaitu 10,4\% dengan risiko yang lebih besar $6,69 \%$.

\section{Tabel 2}

\section{Perbandingan Investasi Saham A dan} Saham B

Sumber: Data diolah

Seorang investor haruslah seorang yang rasional, dalam arti mempertimbangkan apakah risiko yang harus diambil sebanding dengan keuntungan yang diharapkan E (R). Ukuran rasional adalah koefisien variasi $\mathrm{CV}$ yang dirumuskan sebagai risiko $\sigma$ dibagi dengan hasil yang diharapkan $E(R)$, yang menunjukkan bahwa semakin kecil CV semakin kecil risiko dan sebaliknya semakin besar CV semakin besar risiko. Maka pilihan adalah Saham A.

Kriteria Investasi, Spekulasi dan Judi 
Judi menurut (Borna and Lowry, 1987) bahwa coming from an economic perspective, gambling as reallocation of wealth, on the basis of deliberate risk, involving gain to one party and loss to another, usually without the introduction of productive work on either side.Kriteria investasi, spekulasi, dan judi dapat dijelaskan dengan perhitungan yang tampak dalam Tabel 3 .

Tabel 3

Contoh Perhitungan dan Kriteria Investasi, Spekulasi, dan Judi

\begin{tabular}{|c|c|c|c|c|}
\hline & Probabilitas & Hasil & Hasil yang Diharapkan & Keterangan \\
\hline \multicolumn{5}{|c|}{ Uang logam: } \\
\hline - Menang & 0,50 & 1 & \multirow{2}{*}{$0,50(1)+0,50(-1)=0$} & \multirow{2}{*}{$\begin{array}{c}\text { Spekulasi / } \\
\text { zero sum game }\end{array}$} \\
\hline - Kalah & 0,50 & -1 & & \\
\hline \multicolumn{5}{|l|}{ Undian: } \\
\hline - Menang & 0,01 & 60 & \multirow{2}{*}{$0,01(60)+0,99(-1)=-0,39$} & \multirow{2}{*}{$\begin{array}{c}\text { Judi / } \\
\text { gambling }\end{array}$} \\
\hline - Kalah & 0,99 & 1 & & \\
\hline
\end{tabular}

Kalau bertaruh uang koin dalam ilustrasi Tabel 2.3, apabila dilempar ke atas, maka akan jatuh gambar atau angka. Probabilitas menang dan kalah 0,50. Apabila menang maka akan memperoleh 1, dan apabila kalah maka akan kehilangan 1. Sehingga hasil yang diharapkan E (R) dari bertaruh uang koin akan sama dengan nol. Hal ini berarti bahwa bertaruh uang koin merupakan spekulasi. Sementara ketika kita membeli undian katakan Togel merupakan judi karena probabilitas menang hanya 1 dibandingkan dengan 100 angka yang ada dan apabila menang akan memperoleh hasil 60 kali lipat, sementara probabilitas kalah adalah 0,99 hanya akan kehilangan 1. Dengan demikian hasil yang diharapkan adalah -0,39 (negatif)

Berdasarkan kriteria di atas, jelas menunjukkan bahwa hasil yang diharapkan dari suatu investasi positif, sementara hasil yang diharapkan dari spekulasi adalah nol, dan hasil yang diharapkan dari judi adalah negatif.

\section{Penelitian Sebelumnya}

Studi terdahulu dilakukan oleh (Arthur, Jennifer N. et.all, 2016) memberikan hasil bahwa judi berbeda dari investasi pada banyak atribut berbeda dan seharusnya dilihat sebagai perbedaan secara konseptual. Di lain pihak spekulasi secara konseptual dengan beberapa atributnya jelas mirip judi atau investasi. (Kumar, 2009) menunjukkan bahwa propensity to gamble and investment decisions are correlated. Hasil ini menunjukan bahwa loterai Negara dan saham jenis loterai menarik bagi pembeli dengan sosioekonomi sama.
Saham yang mirip loterai dengan kinerja buruk lebih banyak pada investor dengan penghasilan rendah.

Secara empiris menunjukkan bahwa investor retail tertarik pada perusahaan yang volatile dan bukan dari harapan profit, karena para agen lebih tertarik dengan perusahaan yang volatile, dibandingkan dengan perusahaan yang mempunyai cash flow lebih mapan. Sementara (Alkhadher, Othman, 2009) menunjukkan bahwa Trader's satisfaction with his/her financial achievement was not correlated with any of these measures.

Para investor mungkin mempunyai tujuan berbeda, banyak investor yang lebih suka capital gain, padahal investasi sebenarnya tindakan mencari keuntungan dengan return jangka panjang (Karki, Bushan, and Adhikari, 2015). Sumber utama return adalah laba perusahaan dan investasi berdasarkan informasi dan analisis, di lain pihak spekulasi adalah fenomena jangka pendek yang melibatkan pembelian marketable securities dengan harapan memperoleh hasil besar dalam jangka pendek. lebih lanjut bahwa kebanyakan investor mempunyai motif spekulasi dan hanya sedikit investor yang mempunyai motif investasi atau judi.

\section{Kerangka Pemikiran Teoritis}

Studi ini melihat bahwa terdapat perbedaan persepsi tentang investasi dalam saham di masyarakat. Investasi dalam saham dianggap sebagai judi, sehingga masyarakat ragu untuk melakukan investasi dalam saham. 
Studi ini akan membahas mengenai investasi saham, kriteria investasi, judi dan spekulasi, yang dimulai dari perusahaan sebagai penerbit saham yang harus menunjukkan kinerja keuangan yang baik untuk menarik minat para investor. Sementara itu para investor mempunyai harapan akan dividend dan capital gain dalam melakukan pembelian saham. Keputusan pembelian saham tergantung pada sikap investor itu sendiri. Kerangka pemikiran teoritis dapat dilihat dalam Gambar 1:

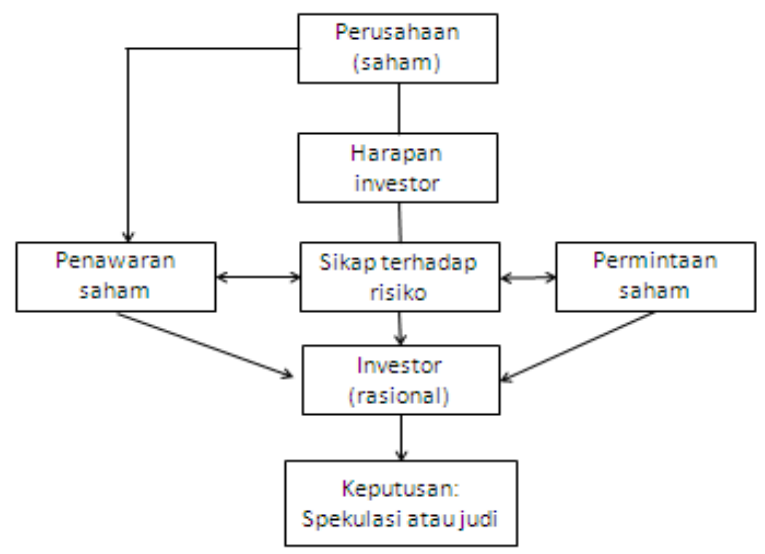

\section{Gambar 1 Pemikiran Teoritis}

\section{METODE PENELITIAN}

Studi ini menggunakan metode dengan kerangka pemikiran teoritis yang dibagi dalam beberapa tahap. Tahap pertama dijelaskan secara konseptual mengenai saham dan mekanisme perdagangan saham. Tahap kedua adalah membahas mengenai kriteria yang digunakan untuk menentukan investasi, spekulasi dan judi. Tahap ketiga adalah dasar pengambilan keputusan investor untuk membeli dan menjual saham. Tahap akhir adalah hasil dan diskusi dilanjutkan dengan simpulan dan saran.

\section{PEMBAHASAN}

Seperti telah dijelaskan bahwa saham merupakan bukti kepemilikan perusahaan dan mekanisme perdagangan saham dilakukan di Bursa Efek di bawah pengawasan dari Bapepam, yang berarti dijamin oleh pemerintah. Hal ini menunjukkan bahwa saham bukanlah ilegal.

Investasi berbeda dengan spekulasi dan judi berdasarkan kriteria yang dijelaskan dalam Tabel 4. Tabel 4 menunjukkan bahwa investasi saham bukanlah judi, tetapi bisa dipandang sebagai investasi dan atau spekulasi. Hal ini dapat dilihat dari beberapa faktor yaitu aktiva, hasil yang diharapkan, risiko, kemanfaatan, jangka waktu, harapan investor.

Investasi saham dikatakan sebagai investasi karena aktiva yang diperdagangkan jelas yaitu saham dan dijamin oleh pemerintah karena diawasi oleh Bapepam dengan UU No. 8 tahun 1995 tentang Pasar Modal. Hal ini berarti bahwa aktiva dalam bentuk saham yang merupakan bukti kepemilikan akan tetap menjadi milik dan tidak akan hilang, namun judi tidak ada aktiva yang diperdagangkan, sehingga uang yang dikeluarkan akan hilang ketika kalah dalam pertaruhan.

\section{Tabel 4}

\begin{tabular}{lccc}
\multicolumn{4}{c}{ Perbedaan Investasi, Spekulasi, dan Judi } \\
\hline \multicolumn{1}{c}{ Aktiva } & $\begin{array}{c}\text { Ada } \\
\text { (saham) }\end{array}$ & $\begin{array}{c}\text { Kadang } \\
\text { Ada }\end{array}$ & Tidak Ada \\
\hline $\begin{array}{l}\text { Hasil yang } \\
\text { diharapkan }\end{array}$ & Positif & Nol (0) & Negatif \\
\hline Risiko & Sebanding & Tinggi & Tinggi \\
\hline Kemanfaatan & Tinggi & Mixed & Rendah \\
\hline Jangka waktu & panjang & mixed & pendek \\
\hline Harapan & $\begin{array}{c}\text { Dividend } \\
+ \text { capital } \\
\text { gain }\end{array}$ & $\begin{array}{c}\text { Capital } \\
\text { gain }\end{array}$ & Hasil tinggi \\
\hline Sikap investor & Rasional & Kadang & $\begin{array}{c}\text { Tidak } \\
\text { rasional }\end{array}$ \\
\hline
\end{tabular}

Hasil yang diharapkan atau expected return saham adalah positif, sementara judi mengharapakan hasil yang negatif. Hal ini menunjukkan bahwa yang diharapkan berbeda, bahwa judi sudah tidak rasional. Tabel 2 menunjukkan bahwa hasil yang diharapkan atau expected return dari saham A sebesar 9,5\% dan saham B adalah 10,4\%. Sementara judi seperti ditunjukkan dalam Tabel 3, bahwa hasil yang diharapkan dari judi adalah sebesar $-0,39$.

Investasi dalam saham dikatakan investasi karena risiko yang ditanggung sebanding dengan hasil yang diharapkan. Tabel 2 menunjukkan bahwa seseorang dapat melakukan pembelian saham dengan membandingkan kedua saham yaitu saham A dan saham B dengan menggunakan ukuran koefisien variasi. Pilihan adalah saham A karena mempunyai $\mathrm{cv}$ atau koefisien variasi lebih kecil yaitu 0,43, menunjukkan bahwa hasil yang diharapkan sebanding dengan risiko yang harus ditanggung. Hal ini berbeda dengan judi yang dapat dilihat dari Tabel 3, bahwa probabilitas menang hanya $1 \%$ atau 0,01 , artinya bahwa kemungkinan menang sangat kecil, dengan hasil yang diharapkan negatif. 
Investasi mempunyai kemanfaatan tinggi, hal ini bisa dijelaskan bahwa, investasi saham berarti menanamkan modal untuk memperoleh dividen atau pembagian laba yang sifatnya jangka panjang dan capital gain atau keuntungan saham dari perdagangan saham itu sendiri yang sifatnya jangka pendek. Hal ini menunjukkan bahwa investor akan memperoleh penghasilan baik jangka panjang maupun jangka pendek.

Ditinjau dari sikap investor, yaitu risk taker, indifferent to risk dan risk averter, di mana investor haruslah rasional dalam arti mengharapkan dividen dan capital gain. Sikap investor yang risk taker akan cenderung melakukan spekulasi atau liquidity trader, yang mengharapkan hasil segera dari naik turunnya harga saham. Sikap investor yang risk averter akan cenderung melakukan investasi jangka panjang dengan menghadapkan dividen, yang disebut juga information trader. Sementara orang yang tidak peduli atau indifferent to risk, maka tidak akan melakukan investasi.

Dengan demikian dapat disimpulkan bahwa sebenarnya investasi saham bukan judi, namun investasi atau spekulasi adalah tergantung pada sikap orang terhadap risiko. Selain itu juga niat dari investor sendiri, apakah berniat untuk investasi ataukah spekulasi.

Berdasarkan pada risiko, bahwa judi tidak bisa mengurangi risiko, sekali seseorng melakukan judi, maka tidak ada cara untuk mengurangi risiko yang ditimbulkan. Namun investasi maupun spekulasi bisa melakukan berbagai strategi untuk mengurangi risiko.

Berbagai cara dapat dilakukan untuk dapat mengurangi risiko investasi saham, yaitu menganalisis kinerja keuangan perusahaan. Selain itu bisa juga mengurangi risiko dengan cara melakukan portofolio. Portofolio adalah kumpulan investasi, jadi ketika investor membeli saham, sebaiknya tidak hanya membeli satu saham saja, tetapi beberapa saham dalam portofolio investasi. Seorang investor yang memiliki portofolio dengan melakukan diversifikasi yaitu melakukan pemilihan dari banyak saham yang ada di pasar modal. Prinsip yang digunakan adalah don't put your money in one basket. Hal ini menunjukkan bahwa ketika salah satu saham mengalami kerugian maka saham yang lain dapat mengkover kerugian tersebut. Dengan demikian investor tidak mengalami kerugian yang besar.

\section{PENUTUP}

\section{Kesimpulan}

Menjawab pertanyaan studi ini bahwa investasi dalam saham bukanlah judi, tetapi investasi, bisa juga spekulasi. Ketika investor rasional maka ia mengharapkan dividend (jangka panjang) dan capital gain (jangka pendek) sekaligus, maka ini disebut dengan investasi. Ketika investor hanya mengharapkan naik turunnya saham atau capital gain (jangka pendek) berarti dapat dikatakan spekulasi. Namun semua ini tidak lepas dari sikap dan niat dari investor itu sendiri. Kriteria yang digunakan sebagai pegangan adalah aktiva, hasil yang diharapkan, risiko, kemanfaatan, jangka waktu, harapan investor, serta sikap dari investor itu sendiri.

\section{Implikasi}

Seorang investor yang melakukan investasi khususnya saham haruslah rasional dalam arti bahwa risiko yang ditanggung sebanding dengan hasil yang diharapkan dengan menggunakan ukuran koefisien variasi. Semua kembali pada sikap dan niat investor itu sendiri.

\section{Keterbatasan}

Studi ini hanya memberikan pandangan dari perspektif teoritis, perlu pengembangkan lebih lanjut dengan menggunakan data empiris untuk melihat lebih jauh mengenai pemahaman masyarakat terutama investor dalam investasi saham dengan deep interview.

\section{DAFTAR PUSTAKA}

Alkhadher, Othman. 2009. Trader's gambling addiction in Kuwaiti and Saudi Stock Markets. https://www.papers.ssrn.com

Arthur, Jennifer N. et. Al. 2016. The Conceptual and Empirical Relationship between Gambling, Investing and Speculation. Journal of Behavioral Addiction https://www.researchgate.net

Bacidore, J.M, John, A.B., Todd T.M., and Anjan, V.T. 1997. The search for the Best Financial Performance Measure. Financial Analysts Journal, May/June

Borna and Lowry. 1987. Gambling and Speculation, Journal of Business Ethics 1987, https://www.researchgate.net

Fama, E. 1955. The Behavior of Stock Market Prices. Journal of Business, January, p.36

Karki. Bushan. and Adhikari, Bibhav. 2015. Investment motives of individual investor in 
the stock of market of Nepal. Components. Journal of Accounting and https://www.papers.ssrn.com Economics 13, 25-46, North-Holland.

Kumar, Alok. 2009. Who gambles in the stock Undang-Undang Pasar Modal No. 8 tahun 1995 market? The Journal of Finance, https://www.researchgate.net

tentang Pasar Modal. https://www.ojk.go.id

Livnat J., and Paul Zarowin. 1990. The Incremental Information Content of Cash Flow 